\title{
Common mental disorders among health care students
}

\author{
Transtornos mentails comuns em estudantes da área \\ de saúde
}

\author{
Vera Lúcia Dutra Facundes, ${ }^{1}$ Ana Bernarda Ludermir ${ }^{2}$
}

\author{
Original version accepted in Portuguese
}

\begin{abstract}
Objectives: This study aimed to determine the prevalence of common mental disorders (CMDs) among the population of graduate students in Physical Education, Nursing, Dentistry and Medicine at the University of Pernambuco, as well as to analyze the relationship between CMDs and some characteristics of the teaching-learning process. Methods: A cross-sectional study was carried out in the second semester of 2001 involving all students in the second and sixth semesters of each course. A total of 443 students responded to two self-reporting questionnaires: the Self Reporting Questionnaire-SRQ-20 and another questionnaire regarding characteristics of the teaching-learning process. Results: The overall prevalence of CMDs was $34.1 \%$ and was significantly higher among students who felt overloaded $(O R=2.67 ; 95 \% \mathrm{Cl}=1.6-4.5)$ or reported special situations during childhood and adolescence $(O R=2.55 ; 95 \% \mathrm{Cl}=1.5-4.4)$. Conclusion: These findings can serve as the basis for development of programs of disease prevention and student mental health care, as well as collaborating with reflections on the teaching-learning processes in university courses.
\end{abstract}

Keywords: Mental disorders; Students, Health occupations; Mental health; Teaching; Learning

\begin{abstract}
Resumo
Objetivos: O estudo objetivou determinar a prevalência de Transtornos mentais comuns (TMC) na população de estudantes dos cursos de graduação em Educação Física, Enfermagem, Odontologia e Medicina, da Universidade de Pernambuco, e analisar a sua associação com algumas características do processo ensino-aprendizagem. Métodos: Um estudo transversal foi conduzido, no $2^{\circ}$ semestre de 2001, com todos os estudantes dos $2^{\circ}$ e $6^{\circ}$ períodos de cada um dos cursos envolvidos. Um total de 443 alunos respondeu ao Self Reporting Questionnaire-SRQ-20 e a um questionário sobre as características do processo ensino-aprendizagem. Resultados: A prevalência total dos transtornos mentais comuns foi de $34,1 \%$, sendo significativamente maior entre os que se sentiam sobrecarregados $(O R=2,67$ IC95\% 1,6-4,5) e os que afirmaram a presença de situações especiais durante a infância e adolescência (OR = 2,55 IC95\% 1,5-4,4). Conclusão: Estes resultados são importantes para subsidiar ações voltadas para a prevenção e o cuidado com a saúde mental dos estudantes, assim como para colaborar com reflexões acerca do processo ensino-aprendizagem nos cursos universitários.
\end{abstract}

Descritores: Transtornos mentais; Estudantes de ciências da saúde; Saúde mental; Ensino; Aprendizagem

Article based on the Masters thesis "Prevalence of Common Mental Disorders in health care students at Universidade de Pernambuco (UPE) and its association with some of the characteristics of the teaching-learning process" by Vera Lúcia Dutra Facundes, defended before the Masters in Collective Health Committee at UFPE on 15 May, 2002.

1 Department of Occupational Therapy, Health Sciences Center, Universidade Federal de Pernambuco (UFPE), Recife (PE), Brazil

2 Department of Social Medicine, Health Sciences Center, Universidade Federal de Pernambuco (UFPE), Recife (PE), Brazil

Financing: Programa Institucional de Bolsa de Iniciação Científica (PIBIC), Conselho Nacional de Desenvolvimento Científico e Tecnológico $(\mathrm{CNPq})$, process 40040

Conflicts of interests: None

Submitted: 14 April 2004

Accepted: 2 August 2004

\section{Correspondence}

Vera Lúcia D Facundes

R. Padre Inglês, $n^{\circ}$ 178/13, Boa Vista

50050-230 Recife, PE

Phones: (81) 3423-6375 (home)/ 2126-8931 (UFPE)/

9978-9957 (cellular)

Fax: (81) 2126-8590

E-mail: verafacundes@yahoo.com.br 


\section{Introduction}

Student integration into a university is a multifaceted process achieved during the daily routine through relationships established between the expectations and abilities of the students and the structure and norms of the institution. According to Polydoro et al, ${ }^{1}$ this process involves two important factors: 1) external aspects of the academic and social environment and 2) internal aspects of the individual, such as ability to face situations, psychosomatic physical reactions and mood state. ${ }^{1}$ According to the authors, these aspects are related to higher education in a broader manner, independent of the specifics of each course.

In the field of health care, some characteristics of the teaching process and of the reality of university life for students in some courses have been implicated as conflict generators, able to negatively affect student academic performance, physical health and psychological well-being. ${ }^{2-3}$

Most studies conducted in this area have focused on medical students and courses, considering the vicissitudes of the course itself, which expose students to sources of tension, from the admission process to graduation. Such stress factors include coming into contact with death and with innumerable pathological processes, performing the first physical exam on a patient, fear of acquiring diseases and feelings of inadequacy when confronting certain diseases. All of this may lead the students to engage psychological defense mechanisms such as dissociation or isolation of the affect. ${ }^{4-7}$ Roberts et al $^{7}$ showed that approximately one-fourth of medical students in the USA present symptoms of mental distress. In a study conducted in nine American medical schools, the authors found that approximately $90 \%$ of students reported requiring medical attention due to various health problems, and $46 \%$ presented at least one of the psychiatric symptoms investigated (stress, fatigue, anxiety, depression, headache and eating disorders) during the course.

The psychological well-being of university students in other courses of health care, such as nursing ${ }^{3,8-9}$ and dentistry, ${ }^{10-11}$ has also been investigated. Among these studies, the results were similar in terms of the signs of psychic distress exhibited by students when facing difficulties related to performance in academic activities. These challenges include fear of making mistakes, time management in juggling a great number of activities, lack of motivation to study, low academic performance and difficulty in integrating several subjects. In addition, lack of teacher support and counseling, relationship difficulties with colleagues and relatives, and social/financial adaptation can all be aggravating factors.

A study recently conducted at the Federal University of Santa Maria ${ }^{4}$ using the Self-Reporting Questionnaire (SRQ-20), showed that the prevalence of minor psychiatric disorders among students in the first to the tenth semester of medical school was $31.7 \%$. The authors found that mental distress was not statistically associated with gender, marital status or place of residence and added that this prevalence may be considered high, especially when compared to the 19\% found among students at the Federal University of Pelotas School of Medicine. ${ }^{4}$

Minor psychiatric disorders, also known as common mental disorders (CMDs), are commonly found in this population and affect the performance of daily activities. The CMD symptoms include insomnia, fatigue, irritability, forgetfulness and difficulty in concentrating, as well as somatic complaints, but do not encompass psychotic disorders, chemical dependence or personality disorders. ${ }^{12}$

In the present study, the investigation was limited to students in the area of health care. We understand that it is more prudent to compare these students among themselves since they have subjects in common and their activities often overlap, both during training and in practice. The objectives of this study were to identify the prevalence of CMDs among graduate students in the courses of medicine, nursing, dentistry and physical education at the University of Pernambuco (UPE) and to determine the association between CMD prevalence and some characteristics of the teaching-learning process.

\section{Methods}

\section{Setting}

The UPE belongs to the government of the state of Pernambuco. Of the 13,500 graduate students, 2582 are enrolled in courses in the area of health care. ${ }^{13}$

\section{Study design and data collection}

A prevalence study was conducted during the months of August, September and October of 2001.

A pilot study involving graduate students in the areas of medicine and occupational therapy at the UFPE was conducted, aiming to test the language used in the instruments and the receptivity of the students to the study. This process was also part of the training course for research assistants, both refining the questionnaire on the characteristics of the teaching-learning process and improving the manner in which the instruments are applied.

The researchers were informed by the coordinators of the courses about the impossibility of identifying students by semester, since the curricular flexibility allows a student who falls behind in a course, due to failing or for any other reason, to attend courses in other disciplines in the subsequent semester. Two reference disciplines were then selected, one in the second and the other in the sixth semester, of each of the courses studied. The global aspect of the study included all students enrolled in these disciplines. The questionnaires and the informed consent forms were introduced and distributed to the students in the classroom. Each classroom was visited more than once (maximum, three times), with the intention of gaining the participation of all of the students in each discipline. Any student who did not fill out or did not return the questionnaire was considered a "loss".

\section{Research instruments}

\section{1) Self Reporting Questionnaire-20 (SRQ-20)}

The Self-Reporting Questionnaire (SRQ-20) is an instrument designed by the World Health Organization and consists of twenty yes-no questions, four about physical symptoms and sixteen about psychological-emotional disorders. ${ }^{14}$ These questions were answered in the present study considering the past 30 days. One of the motivations for choosing the SRQ-20 was that it has been validated in a nationwide study conducted in Brazil, ${ }^{15}$ in which the sensitivity and specificity were reported to be $85 \%$ and $80 \%$, respectively, comparable to the $62 \%$ and $80 \%$ reported for the state of Pernambuco. ${ }^{16-17}$ In addition, this questionnaire has also been used in a study involving medical students, ${ }^{4}$ which enabled comparison with our results. The students were divided into two groups, according to SRQ-20 scores. Men with scores equal to or less than five and women with scores equal to or less than seven were classified as "nonsuspect", whereas men with scores equal to or greater than six and women with scores equal to or greater than eight were classified as "suspect".

2) Questionnaire regarding characteristics of the

\section{teaching-learning process}

Data regarding characteristics of the teaching-learning process were obtained through the use of an objective questionnaire, 
consisting mainly of closed questions and constructed according to a bibliographic review. ${ }^{2}$ The questionnaire presents questions regarding sociodemographic variables (sex, age, place of residence, origin, personal income and family income), previous history of psychiatric or psychological treatment, and characteristics of the teaching-learning process. The last category includes questions regarding most often employed teaching strategies, classification of teacher-student relationships, main study modes, weekly schedule of academic activities and sources of tension in the course, as well as the reason for choosing the course and number of university entrance exams taken. In order to minimize the difficulties in identifying the time sequence of the events, questions regarding situations suggestive of pre-existing psychological distress, as well as questions regarding special situations during childhood and adolescence, were also included.

Additional clarifications regarding some of the variables assessed:

- Semester: defined within the curricular structure of each course and categorized as initial (second semester) or intermediate (sixth semester).

- Opting for the course: principal factor that motivated the students to choose the course, with alternatives such as: the expanding work field, identification with the profile of the course, failing in previous university entrance exams, and others (family influence, social status of the course, perceived obstacles to pursuing their course of choice).

- Number of entrance exams taken for admission to the current course: 1 entrance exam or more than 1 entrance exam.

- Teaching-learning strategies divided into the categories: classes in theory that are totally teacher-centered or involve dynamic reading with student participation; debates or seminars involving the entire class; practical classes including clinical practice development, featuring dramatizations and role performance, or involving case studies.

- Teacher-student relationship: characterized as repeated meetings at predetermined time intervals, usually weekly, and over a described period (semester or academic year), with the objective of facilitating the student learning process. Relationships were divided by category: teacher-centered or with a predominance of this approach and other (predominantly student-centered or balanced between teacher-centered and student-centered aspects).

- Mode of learning: individual study, practical lessons, classes in theory, or group study.

- Weekly academic activity schedule: Consisting of classes, monitoring, internships, research, etc. and categorized as either 20 to 30 hours or more than 30 hours.

- Activity overload: feeling overwhelmed by a perceived excess in the number of academic activities.

- Sources of tension in the course: schedule of academic activities, demands of evaluations, relationship difficulties (colleagues, professors, patients or clients), Project or seminar presentations, practical classes with clients and patients).

- Situations suggestive of psychic suffering prior to the execution of the study: drug treatment for psychiatric disorders, a history of psychotherapy, (prior to the study onset), current psychotherapy (in process during the study) beginning prior to the study onset) and special situations during childhood and adolescence (situations suggestive of difficulties, especially related to academic performance or social interaction).

- Special situations during childhood or adolescence: defined as present (yes) in those who reported the following: illness that has affected social interaction, failing a grade in school, difficulty in making friends, difficulties in asking questions due to shyness, fears that have affected academic performance or social relationships, insomnia, physical discomfort related to academic evaluations, difficulties in relating to authority figures, difficulty in relating to parents, parent-teacher conferences regarding student behavior, lack of interest in affectionate relationships, or difficulties in reconciling study with pleasure.

\section{Data analysis}

Data were analyzed using the program Stata 6.0 for Windows. Associations between variables (independent and covariables) and CMDs were investigated, and the simple and adjusted odds ratios (OR) were calculated as an approximate estimation of the prevalence ratio was made. Statistical significance was evaluated using $p$ values and the chi-square test, with a respective 95\% confidence interval $(95 \% \mathrm{Cl})$. Logistic regression was used with the aim of analyzing the independence of the association of each variable with CMDs. The variables included in the model were those that have been described in the literature as potential confounding factors and have been shown significant associations among themselves and with CMDs in the present study. In order to compare the various models, a likelihood ratio test was conducted, and values of $p \leqslant 0.05$ were considered statistically significant.

\section{Ethical considerations}

This research was submitted to the Ethics in Research Committee of the Health Sciences Center of the UFPE (Research Protocol $n^{\circ}$ 085/2001-CEP/CCS - attached) and was approved in accordance with Resolution n 196/96, of the National Health Counsel.

\section{Results}

Of a total of 461 students, 443 (96.09\%) completed the questionnaires, $10(2.16 \%)$ declined to participate, and 8 $(1.73 \%)$ were considered lost since they were not present in the classroom when the questionnaires were administered. Tables 1 to 3 show the distribution of independent and

Table 1 - Distribution of the study population by demographic and socioeconomic variables and correlations with common mental disorders

\begin{tabular}{|c|c|c|c|c|c|}
\hline Variable & $n=443$ & $\%$ & Cases & $\%$ & $\mathbf{p}$ \\
\hline \multicolumn{6}{|l|}{ Gender } \\
\hline Female & 309 & 69.8 & 108 & 35.0 & \\
\hline Male & 134 & 30.2 & 43 & 32.1 & 0.55 \\
\hline \multicolumn{6}{|l|}{ Age } \\
\hline $17-19$ & 114 & 25.7 & 36 & 31.6 & \\
\hline $20-22$ & 240 & 54.2 & 80 & 33.3 & \\
\hline$\geq 23$ & 89 & 20.1 & 35 & 39.5 & 0.48 \\
\hline \multicolumn{6}{|l|}{ Lives with } \\
\hline Parents or Relatives & 399 & 90.1 & 129 & 32.3 & \\
\hline Others & 44 & 9.9 & 22 & 50.0 & 0.02 \\
\hline \multicolumn{6}{|l|}{ Origin' } \\
\hline RMR & 325 & 75.0 & 103 & 31.7 & \\
\hline Another region in PE & 70 & 16.2 & 30 & 42.9 & \\
\hline Another state & 38 & 8.8 & 17 & 44.7 & 0.08 \\
\hline \multicolumn{6}{|l|}{ Personal income } \\
\hline No & 368 & 83.1 & 127 & 34.5 & \\
\hline Yes & 75 & 16.9 & 24 & 32.0 & 0.67 \\
\hline \multicolumn{6}{|c|}{ Financially independent ${ }^{2}$} \\
\hline No & 425 & 97.5 & 146 & 34.4 & \\
\hline Yes & 11 & 2.5 & 3 & 27.3 & 0.62 \\
\hline \multicolumn{6}{|l|}{$\begin{array}{l}\text { Financially dependent } \\
\text { upon }\end{array}$} \\
\hline Parents or Relatives & 408 & 97.6 & 141 & 34.6 & \\
\hline Others & 10 & 2.4 & 4 & 40.0 & 0.72 \\
\hline
\end{tabular}


Table 2 - Distribution of the study population by variables in the characteristics of the teaching-learning process and correlations with common mental disorders

\begin{tabular}{|c|c|c|c|c|c|}
\hline Variable & $n=443$ & $\%$ & Cases & $\%$ & $\mathbf{p}$ \\
\hline \multicolumn{6}{|l|}{ Course } \\
\hline Medicine & 141 & 31.8 & 60 & 42.6 & 0.04 \\
\hline Dentistry & 96 & 21.7 & 32 & 33.3 & \\
\hline Nursing & 110 & 24.8 & 35 & 31.8 & \\
\hline Physical Education & 96 & 21.7 & 24 & 25.0 & \\
\hline \multicolumn{6}{|l|}{ Semester ${ }^{1}$} \\
\hline Beginning $\left(2^{\text {nd }}\right)$ & 214 & 48.3 & 77 & 36.0 & 0.48 \\
\hline Intermediate $\left(6^{\text {th }}\right)$ & 222 & 50.1 & 72 & 33.0 & \\
\hline \multicolumn{6}{|l|}{ Reason for opting for the course ${ }^{2}$} \\
\hline Perspective of expanding field of work & 47 & 10.7 & 20 & 42.5 & \\
\hline Identifying with profile of the course & 277 & 62.9 & 87 & 31.4 & \\
\hline Failing other University Entrance exams & 54 & 12.3 & 21 & 38.9 & \\
\hline Others & 17 & 3.9 & 8 & 47.1 & 0.25 \\
\hline \multicolumn{6}{|l|}{ Number of entrance exams taken } \\
\hline 1 exam & 168 & 38.0 & 55 & 32.7 & \\
\hline More than 1 exam & 274 & 61.8 & 96 & 35.0 & 0.62 \\
\hline \multicolumn{6}{|l|}{ Teaching-learning strategies ${ }^{3}$} \\
\hline Deductive theory class or class with dynamic reading and student participation & 348 & 79.6 & 122 & 35.1 & \\
\hline Debates or seminars & 35 & 8.0 & 13 & 37.1 & \\
\hline Practical lessons with role play, clinical practice or case study & 54 & 12.4 & 16 & 29.6 & 0.69 \\
\hline \multicolumn{6}{|l|}{ Teacher-student relationship ${ }^{4}$} \\
\hline Teacher-centered or with a predominance of this approach & 297 & 68.0 & 111 & 37.4 & 0.02 \\
\hline Others & 140 & 32.0 & 37 & 26.4 & \\
\hline \multicolumn{6}{|l|}{ Learning mode ${ }^{5}$} \\
\hline Individual study & 210 & 48.0 & 68 & 32.4 & \\
\hline Practical lessons & 129 & 29.4 & 51 & 39.5 & 0.50 \\
\hline Theoretical lessons & 49 & 11.2 & 16 & 32.6 & \\
\hline Group study & 50 & 11.4 & 15 & 30.0 & \\
\hline \multicolumn{6}{|l|}{ Weekly Schedule of activities ${ }^{6}$} \\
\hline $20-30$ hours & 174 & 40.0 & 48 & 27.6 & \\
\hline More than 30 hours & 261 & 60.0 & 101 & 38.7 & 0.02 \\
\hline \multicolumn{6}{|l|}{ Activity Overload ${ }^{7}$} \\
\hline No & 148 & 33.6 & 28 & 18.9 & \\
\hline Yes & 293 & 66.4 & 122 & 41.6 & $<0.0001$ \\
\hline \multicolumn{6}{|l|}{ Sources of tension ${ }^{8}$} \\
\hline Schedule of academic activities & 176 & 40.4 & 65 & 36.9 & \\
\hline Demand in evaluations & 105 & 24.1 & 33 & 31.4 & \\
\hline Relationship with colleagues and teachers & 42 & 9.6 & 16 & 38.1 & \\
\hline Practical lessons with patients & 10 & 23.6 & 6 & 60.0 & 0.27 \\
\hline Presenting coursework or seminars & 103 & 2.3 & 30 & 29.1 & \\
\hline
\end{tabular}

'10 lost values; ${ }^{2} 48$ lost values; 45 of which were for providing multiple answers; ${ }^{3} 6$ lost values; ${ }^{4} 6$ lost values; ${ }^{5} 5$ lost values; ${ }^{6} 8$ lost values; ${ }^{7} 2$ lost values; ${ }^{8} 8$ lost values

codependent variables and the results of the nonadjusted analysis between CMDs and those variables.

Overall prevalence of CMDs in the studied population was $34.1 \%$. In the bivariate analysis conducted to identify associations of CMDs with the demographic and socioeconomic variables (Table 1), a statistically significant association with CMDs was found only for the variable "not living with parents or relatives" ( $p=0.02)$.

Among the "characteristics of the teaching-learning process" variables (Table 2), the results revealed a higher prevalence of CMDs among medical students (42.6\%) compared with the students in the other courses. Students in the areas of dentistry, nursing and physical education also presented CMD prevalence rates that were considered high $(33.3 \%, 31.8 \%$ and $25 \%$, respectively).

The students who reported that the most frequent type of teacher-student relationship was teacher-centered or with a predominance of this approach presented higher CMD prevalence $(37.4 \%)$, as did those who mentioned a weekly schedule of activities of more than 30 hours (38.7\%) and those who felt overwhelmed (41.6\%).

Analysis of the "situations suggestive of psychological distress prior to the study onset" variables (Table 3 ) showed that only the "presence of specific situations during childhood and adolescence" variable presented a statistically significant association with CMDs ( $p=0.001)$.

Table 3 - Distribution of the study population by variables for situations suggestive of psychological distress prior to the study onset and correlations with common mental disorders

\begin{tabular}{|c|c|c|c|c|c|}
\hline Variable & $n=443$ & $\%$ & Cases & $\%$ & $\mathbf{p}$ \\
\hline \multicolumn{6}{|c|}{$\begin{array}{l}\text { Psychiatric treatment with } \\
\text { drugs }\end{array}$} \\
\hline No & 427 & 96.4 & 143 & 33.5 & \\
\hline Yes & 16 & 3.6 & 8 & 50.0 & 0.17 \\
\hline \multicolumn{6}{|c|}{ Current Psychotherapy } \\
\hline No & 434 & 98.0 & 147 & 33.9 & \\
\hline Yes & 9 & 2.0 & 4 & 44.4 & 0.50 \\
\hline \multicolumn{6}{|c|}{ Past Psychotherapy' } \\
\hline No & 375 & 85.2 & 122 & 32.5 & \\
\hline Yes & 65 & 14.8 & 27 & 41.5 & 0.15 \\
\hline \multicolumn{6}{|c|}{$\begin{array}{l}\text { Presence of special } \\
\text { situations during } \\
\text { childhood and } \\
\text { adolescence }{ }^{2}\end{array}$} \\
\hline No & 109 & 24.8 & 24 & 22.0 & \\
\hline Yes & 331 & 75.2 & 127 & 38.4 & 0.001 \\
\hline
\end{tabular}


Table 4 - Correlations of the course variables: "cohabitants", "teacher-student relationship", "weekly schedule of activities", "overload" and "presence of special situations during childhood and adolescence"

\begin{tabular}{|c|c|c|c|c|c|c|}
\hline \multirow[b]{2}{*}{ Variable } & \multicolumn{3}{|c|}{ Overload } & \multicolumn{3}{|c|}{ Special Situations } \\
\hline & No & Yes & $\mathbf{p}$ & No & Yes & $\mathbf{p}$ \\
\hline \multicolumn{7}{|l|}{ Course } \\
\hline Physical Education & $64(43.2 \%)$ & $31(10.6 \%)$ & & $17(15.6 \%)$ & $77(23.3 \%)$ & \\
\hline Nursing & $21(14.2 \%)$ & $89(30.4 \%)$ & & $36(33.0 \%)$ & $74(22.4 \%)$ & \\
\hline Dentistry & $32(21.6 \%)$ & $64(21.8 \%)$ & & $83(21.1 \%)$ & $73(22.0 \%)$ & \\
\hline Medicine & $31(20.9 \%)$ & $109(37.2 \%)$ & $<0.0001$ & $33(30.3 \%)$ & $107(32.3 \%)$ & $>0.05$ \\
\hline \multicolumn{7}{|l|}{ Living with } \\
\hline Others & $11(7.4 \%)$ & $32(10.9 \%)$ & & $12(11.0 \%)$ & $32(9.7 \%)$ & $>0.05$ \\
\hline \multicolumn{7}{|c|}{ Teacher-student relationship } \\
\hline Teacher-centered & $87(58.8 \%)$ & $209(72.8 \%)$ & $<0.001$ & $74(69.2 \%)$ & $222(67.9 \%)$ & \\
\hline Other & $61(41.2 \%)$ & $78(27.2 \%)$ & & $33(30.8 \%)$ & $105(32.1 \%)$ & $>0.05$ \\
\hline \multicolumn{7}{|c|}{ Weekly Schedule of activities } \\
\hline $20-30 h$ & $95(65.5 \%)$ & $78(27.1 \%)$ & & $34(32.4 \%)$ & $138(42.2 \%)$ & \\
\hline$>30-40 \mathrm{~h}$ & $50(34.5 \%)$ & $210(72.9 \%)$ & $<0.0001$ & $71(67.6 \%)$ & $189(57.8 \%)$ & $>0.05$ \\
\hline \multicolumn{7}{|l|}{ Overload } \\
\hline Yes & & & & $77(70.6 \%)$ & $216(65.6 \%)$ & $>0.05$ \\
\hline \multicolumn{7}{|c|}{$\begin{array}{l}\text { Special situations during } \\
\text { childhood and adolescence }\end{array}$} \\
\hline No & $33(22.1 \%)$ & $77(26.3 \%)$ & & & & \\
\hline Yes & $113(77.9 \%)$ & $216(73.7 \%)$ & $>0.05$ & & & \\
\hline
\end{tabular}

Table 4 shows how the two variables "overload" and "presence of special situations during childhood and adolescence" are associate with the variables: "course", "cohabitants", "teacher-student relationship" and "weekly schedule". The "course", "teacher-student relationship" and "weekly schedule" variables presented statistically significant associations with "overload" but not with "presence of special situations during childhood and adolescence".

Table 5 shows the simple and adjusted odds ratios of the correlations between CMDs and the variables: "course",

Table 5 - Odds ratio (simple, adjusted by "overload", and adjusted by all variables presented in the table)

\begin{tabular}{|c|c|c|c|}
\hline Variable & OR $^{1}$ & $O R^{2}$ & $\mathrm{OR}^{3}$ \\
\hline \multicolumn{4}{|l|}{ Course } \\
\hline Physical Education & 1.00 & 1.00 & 1.00 \\
\hline Nursing & 1.40 & $0.89(0.4-1.7)$ & $0.84(0.4-1.8)$ \\
\hline Dentistry & 1.50 & $1.10(0.5-2.1)$ & $0.99(0.5-2.0)$ \\
\hline Medicine & 2.22 & $1.50(0.8-2.8)$ & $1.21(0.6-2.5)$ \\
\hline \multicolumn{4}{|l|}{ Living with } \\
\hline Parents and relatives & 1.00 & 1.00 & 1.00 \\
\hline Others & $2.09(1.1-3.9)$ & $1.88(1.0-3.6)$ & $1.94(1.0-3.9)$ \\
\hline \multicolumn{4}{|l|}{$\begin{array}{l}\text { Teacher-student } \\
\text { relationship }\end{array}$} \\
\hline Teacher-centered & $1.66(1.1-2.6)$ & $1.47(0.9-2.3)$ & $1.40(0.8-2.3)$ \\
\hline Other & 1.00 & 1.00 & 1.00 \\
\hline \multicolumn{4}{|l|}{$\begin{array}{l}\text { Weekly Schedule of } \\
\text { activities }\end{array}$} \\
\hline $20-30$ hours & 1.00 & 1.00 & 1.00 \\
\hline $30-40$ hours & $1.64(1.1-2.5)$ & $1.23(0.8-1.9)$ & $1.20(0.7-2.0)$ \\
\hline \multicolumn{4}{|l|}{ Overload } \\
\hline No & 1.00 & & 1.00 \\
\hline Yes & $3.06(1.9-5.1)$ & & $2.67(1.6-4.5)^{* *}$ \\
\hline \multicolumn{4}{|c|}{$\begin{array}{l}\text { Special situations during } \\
\text { childhood and adolescence }\end{array}$} \\
\hline No & 1.00 & 1.00 & 1.00 \\
\hline Yes & $2.20(1.3-3.7)$ & $\begin{array}{c}2.41 \\
(1.4-4.0)^{*}\end{array}$ & $\begin{array}{c}2.55 \\
(1.5-4.4)^{* *}\end{array}$ \\
\hline
\end{tabular}

'Simple OR; ${ }^{2}$ Adjusted by overioad; ${ }^{3}$ Adjusted by all variables ${ }^{*} p<0.001 ; \cdots p<0.0001$

$O R$ : odds ratio "cohabitants", "teacher-student relationship", "weekly schedule", "overload" and "presence of special situations during childhood and adolescence". The odds ratios adjusted for "overload" and for all variables in the table showed that "overload" $(\mathrm{OR}=2.67 ; 95 \% \mathrm{Cl}=1.6-4.5)$ and "presence of special situations during childhood and adolescence" $(\mathrm{OR}=2.55 ; 95 \% \mathrm{Cl}=1.5-4.4)$ were the only variables that remained significantly associated with CMDs.

\section{Discussion}

Overall CMD prevalence within the population studied was $34.1 \%$. This value may be considered high when compared to the rates found in population studies conducted in industrialized countries, as reviewed by Goldberg \& Huxley, ${ }^{12}$ in which the prevalence of CMD varied from $7 \%$ to $30 \%$. In Brazilian population studies, rates are within the expected range, according to studies carried out by de Lima et al ${ }^{18}$ and Ludermir, ${ }^{17}$ who reported prevalence of $22 \%$ and $35 \%$, respectively.

The prevalence of CMDs among medical students at the UPE $(42.6 \%)$ was higher than that found in the city of Pelotas, in the state of Rio Grande do Sul (19.0\%) ${ }^{4}$ and at Santa Maria Federal University (31.7\%). ${ }^{4}$ The higher prevalence of CMDs among medical students could be attributed to the number of stressproducing situations that these students are exposed to, in the admission process, during the courses, and throughout the years. The rates of CMD prevalence found among students in the areas of dentistry (33.3\%) and nursing (31.8\%) were also high.

The multivariate analysis showed that only the variables "overload" and "presence of special situations during childhood and adolescence" maintained statistically significant associations with CMDs.

Prior to interpreting the elucidative potential of these variables and identifying the reasons for the fact that we found no correlations between CMDs and certain other variables, it is necessary to investigate the hypothetical existence of sampling error, bias or confounding factors.

The option of working with the entire population of students in the chosen semesters ruled out the possibility of sampling 
error. However, the total number of students in the semesters represented the sample of students for each course, which led us to carry out statistical tests. Regarding the chosen semesters (second and sixth), there is a possibility of biases in the selection. The variable "main sources of tension in the course" could have been conducted differently, since practical lessons with clients, for example, are much more common in the final semesters. Being aware of this question from the study onset, we opted for maintaining our focus on these semesters, since students who are close to completing the course are always involved in off-campus activities (internships, clinical practice, etc.) in small groups, which would hinder the execution of the study. This limitation of the study was considered when the results were interpreted. As for controlling confounding factors, we reiterate that the independent effect of the two variables "overload" and "presence of special situations during childhood and adolescence" on CMDs remained statistically significant, even when the other variables were controlled in logistic regression. Given the cross-sectional nature of the study, in which it is not possible to define the temporal relationship between exposure and disease, we cannot state that the associations observed in the study are of a causal nature. However, in the attempt to minimize the effect of this factor, we researched reports in which psychological distress prior to study onset was suggested by drug treatment or psychotherapy and found that no association with CMDs has been observed. Nevertheless, students who presented special situations during childhood and adolescence presented higher CMD prevalence.

Discussing, therefore, the elucidative potential of the results, we determined that the magnitude of the associations of CMDs with the variables "overload" and "special situations during childhood and adolescence" was considerable. The students who felt overwhelmed and confirmed the presence of special situations during childhood and adolescence presented, respectively, 2.67 times $(95 \% \mathrm{Cl}=1.6-4.5)$ and 2.55 times $(95 \% \mathrm{Cl}=1.5-4.4)$ more CMDs than did those who did not feel overwhelmed and did not present special situations.

In a study conducted by Cianflone \& Fernandez, ${ }^{2}$ medical students felt overwhelmed and identified the greater-than-30hour weekly activity schedule as the source of tension. In the present study, students in the areas of medicine and nursing presented the highest percentages for the "overload" variable, in contrast to that found for physical education students. We can also assume that the degree of "overload" is related to the way in which academic activities are carried out, some provoking this sensation of discomfort in the students. Polydoro et $\mathrm{al}^{1}$ reported that the norms and working structure of the university environment are external aspects essential to the integration of students into university.

Students who experienced school-related and socialization difficulties during primary school or middle school presented a higher prevalence of CMDs at the time of our investigation. This variable ("presence of special situations during childhood and adolescence") was assessed through individual questions (related to internal aspects), also referred to by Polydoro et $\mathrm{al}^{1}$ as being fundamental to the process of student adjustment to university life. Although the questions were intended to refer to situations in the past, we cannot rule out the hypothesis that such situations continue into the university years, further reinforcing the idea that attention should be given to these students.
Having concluded our discussion of the variables "overload" and "presence of special situations during childhood and adolescence", we now turn our attention to those associations not attaining a level of statistical significance.

There was an expectation of finding a predominance of CMDs in women. ${ }^{16-17}$ However, the distribution was similar among females $(35.0 \%)$ and males $(32.1 \%)$. The lack of an association between gender and CMDs in the present study may be explained by the fact that men and women occupy equal positions within the social sphere of the university.

We observed no differences in CMD prevalence between the initial and intermediate semesters. Benvegnú, Deitos \& Copette ${ }^{4}$ also found that medical students presented no differences among semesters in CMD prevalence, which was considered high in both groups. This indicates that both the admission phase and the process of adapting to the academic reality, as well as some characteristics of the teaching-learning process throughout the courses, may affect the emotional well-being of the students.

Most studies of mental health in medical students have identified some characteristics as stress factors (the first physical examination of a patient and fear of acquiring illnesses or of being powerless to deal with certain diseases, as well as coming into contact with death and with innumerable pathological processes). ${ }^{4,6-7}$ The fact that we covered students only up to the sixth semester of each course therefore excluded, especially in the area of medicine, most practical clinical experience, in which students more frequently come into contact with death and a greater number of illnesses.

In view of these facts, it is likely that the variables "overload" and "presence of special situations during childhood and adolescence" are factors that influence the mental health of university students, since they rule out the possibility of systematic errors. In addition, this association meets a number of causality criteria used in epidemiology, and the associaton strength, coherence and consistency are in accordance with other studies. However, the temporal sequence could not be empirically evaluated in relation to the variable "overload", limiting the possibility of establishing a causal connection with CMDs.

\section{Conclusions}

We cannot overstate the importance of reflecting upon the teaching process, especially the manner in which academic activities are distributed throughout the course years. From our point of view, this requires reapportioning the schedule, rather than reducing it, optimizing activities and consequently improving learning while placing fewer burdens on the students. Attention should also be given to the way teaching has been practiced, emphasizing the teacher-student relationship, as well as the teaching strategies, which mostly lack student participation, hindering the preparation necessary for developing the posture of independence and safety required at the beginning of professional life. We also consider it essential to focus on the process of student adaptation to university life since those who presented previous difficulties or problems are more likely to present psychological distress during the academic years. Hence the importance of mental health support services in order to provide for such students, preventing the worsening of symptoms, strengthening healthy mechanisms and increasing the ability to deal with health problems.

The results presented in this study suggest the need for continuity, achieved through a longitudinal study design, in which it would be possible to perform follow-up assessment of the effects 
of the teaching-learning process on the health of the students throughout the courses. We also hope that our results may serve as a basis for the creation of programs dedicated to student health care, as well as to further the discussion about the influence of the teaching-learning process in health. The aim of such discussion should be to seek strategies for relieving psychological distress, which affects academic performance, professional development and overall individual development. This leads us to reflect on the true objectives of universities and, within that context, the roles played by the institutional actors responsible for the professional training offered.

\section{References}

1. Polydoro SAJ, Primi R, Serpa MNF, Zaroni MMH, Pombal KCP. Desenvolvimento de uma escala de integração ao ensino superior. Psico-USF. 2001;6(1):11-7.

2. Cianflone ARL, Fernandez JM. Algumas características do ensino e aprendizado na Faculdade de Medicina de Ribeirão Preto - USP um estudo junto aos alunos de graduação. Medicina (Ribeirão Preto). $1993 ; 26(2): 228-36$.

3. Jorge MSB. Situações vivenciadas pelos alunos de enfermagem durante o curso, no contexto universitário, apontadas como norteadoras de crises. Rev ESC Enfermagem USP. 1996;30(1):138-48.

4. Benvegnú LA, Deitos F, Copette FR. Problemas psiquiátricos menores em estudantes de Medicina da Universidade Federal de Santa Maria, RS, Brasil. Rev Psiquiatr Rio Gd Sul. 1996;18(3):229-33.

5. Millan LR, Souza EN, De Marco OLN, Rossi E, Arruda PCV. O I Encontro Paulista dos Serviços de Assistência Psicológica ao Estudante Universitário. Rev Hosp Clín Fac Med Univ São Paulo. 1998;53(3): 156-61

6. Noto JRS, Avancine MAT, Martins MCFN, Zimmermann VB. Atenção à saúde mental do estudante de medicina. Rev Bras Educ Med. 2001;25(1):72-5.

7. Roberts LW, Warner TD, Liketsos C, Frank E, Ganzini L, Carter D. Perceptions of academic vulnerability associated with personal illness: a study of 1,027 students at nine medical schools. Collaborative Research Group on Medical Student Health. Compr Psychiatry. 2001;42(1):1-15.

8. Figueiredo RM, Oliveira MAP. Necessidades de estudantes universitários para implantação de um serviço de orientação e educação em saúde mental. Rev Latinoam Enfermagem. 1995;3(2):5-18.

9. Jorge MSB, Rodrigues ARF. Serviços de apoio ao estudante oferecidos pelas Escolas de Enfermagem no Brasil. Rev Latinoam Enfermagem. 1995;3(2):59-68.

10. Benjakul P, Cheunarrom C. Student adjustment problems in two dental schools in Thailand. J Dent Educ. 2000;64(5):365-9.

11. Heath JR, Macfarlane TV, Umar MS. Perceived sources of stress in dental students. Dent Update. 1999;26(3):94-8, 100.

12. Goldberg D, Huxley P. Commom mental disorders: a bio-social model. London: Tavistock; 1992

13. UPE [sítio na Internet]. Recife: Universidade Federal de Pernambuco; c2001 [citado 2005 Maio 16]. Disponível em: http://www.upe.br (Menu principal/UPE em números).

14. Harding TW, de Arango MV, Baltazar J, Climent CE, Ibrahim HH, Ladrido-Ignacio $L$, et al. Mental disorders in primary health care: a study of their frequency and diagnosis in four developing countries. Psychol Med. 1980;10(2):231-41.

15. Mari JJ, Williams P. A validity study of a psychiatric screening questionnaire (SRQ-20) in primary care in the city of São Paulo. Br J Psychiatry. 1986;148:23-6.

16. Ludermir AB. Inserção produtiva, gênero e saúde mental. Cad Saúde Pública. 2000;16(3):647-59.

17. Ludermir AB, Melo Filho DA. Condições de vida e estrutura ocupacional associadas a transtornos mentais comuns. Rev Saúde Pública. 2002;36(2):213-21

18. Lima MS, Beria JU, Tomasi E, Conceição AT, Mari JJ. Stressful life events and minor psychiatric disorders: an estimate of the population attributable fraction in a Brazilian community-based study. Int J Psychiatry Med. 1996;26(2):211-22. 